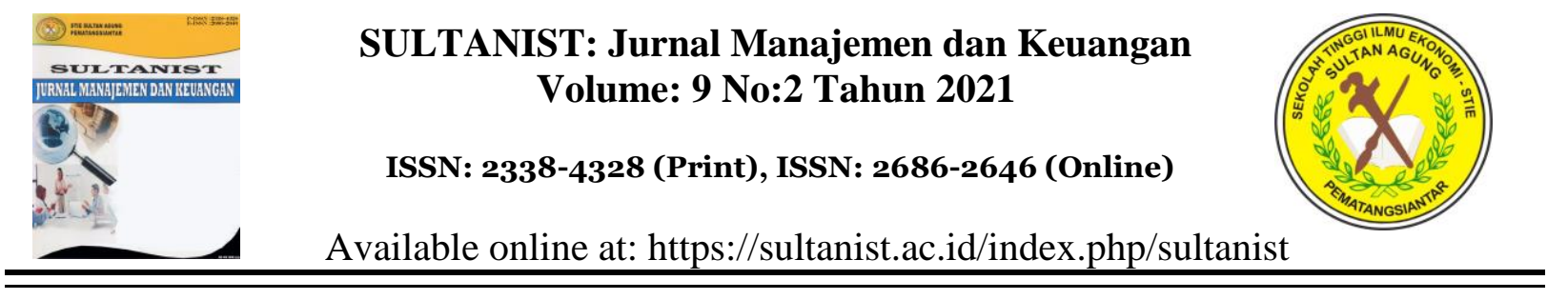

\title{
PENGARUH KINERJA DOSEN, KUALITAS PELAYANAN, DAN FASILITAS TERHADAP KEPUASAAN MAHASISWA UNIVERSITAS MUHAMMADIYAH BENGKULU
}

\author{
Islamuddin $^{1) *}$, Khairul Bahrun ${ }^{2)}$ Ade Tiara Yulinda ${ }^{3)}$ Tongam Sihol Nababan $^{4)}$ \\ ${ }^{1}$ Program Studi Manajemen, Universitas Muhammadiyah Bengkulu \\ ${ }^{2}$ Program Studi Manajemen, Universitas Muhammadiyah Bengkulu \\ ${ }^{3)}$ Program Studi Manajemen, Universitas Muhammadiyah Bengkulu \\ ${ }^{4)}$ Fakultas Ekonomi, Universitas HKBP Nommensen
}

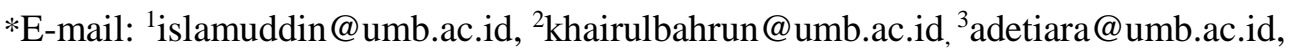
sihol.nababan@uhn.ac.id ${ }^{4}$

\begin{abstract}
Abstrak
Penelitian ini bertujuan untuk mengetahui Pengaruh Kinerja Dosen, Kualitas Pelayanan, dan Fasilitas Terhadap Kepuasan Mahasiswa Universitas Muhammadiyah Bengkulu. Jenis Penelitian yang digunakan dalam penelitian ini adalah metode deskriptif kuantitatif. populasi dalam penelitian ini adalah mahasiswa Universitas Muhammadiyah Bengkulu. sampel yang digunakan pada penelitian ini sebanyak 637 orang responden. Teknik pengumpulan data menggunakan Kuesoner. Teknik analisis data dengan menggunakan Uji Regresi Linier Berganda, dan Uji Hipotesis yaitu Uji T dan Uji F. Hasil penelitian ini dapat disimpulkan bahwa variabel Kinerja Dosen berpengaruh Positif dan signifikan terhadap Kepuasan Mahasiswa, Kualitas Pelayanan berpengaruh Positif dan signifikan terhadap Kepuasan Mahasiswa, kemudian Fasilitas berpengaruh terhadap Kepuasan Mahasiswa, dan Kinerja Dosen, Kualitas Pelayanan dan Fasilitas secara bersama-sama berpengaruh positif dan signifikan terhadap Kepuasan Mahasiswa Universitas Muhammadiyah Bengkulu.
\end{abstract}

Kata kunci: Kinerja Dosen, Kualitas Pelayanan, Fasilitas, dan Kepuasan Mahasiswa

\section{THE EFFECT OF LECTURER PERFORMANCE, QUALITY OF SERVICE AND FACILITIES ON STUDENT SATISFACTION OF MUHAMMADIYAH UNIVERSITY BENGKULU}

\begin{abstract}
This study aims to determine the effect of lecturer performance, service quality and facilities on student satisfaction at the University of Muhammadiyah Bengkulu. The type of research used in this research is descriptive quantitative method. the population in this study were students of the University of Muhammadiyah Bengkulu. The sample used in this study was 637 respondents. Data collection techniques using a questionnaire. The data analysis technique uses Multiple Linear Regression Test, and Hypothesis Testing, namely T Test T-test and $F$ Test F-test. The results of this study can be concluded that the Lecturer Performance variable has a positive and significant effect on Student Satisfaction, Service Quality has a positive and significant effect on Student Satisfaction, then Facilities have an effect on Student Satisfaction, and Lecturer Performance, Service Quality and Facilities together have a positive and significant effect on Student Satisfaction at the University of Muhammadiyah Bengkulu.
\end{abstract}

Keywords: Lecturer Performance, Service Quality, Facilities, and Student Satisfaction

Article History: Received: 02 Oktober 2021 Revised: 22 November 2021 Accepted: 24 November 2021 


\section{SULTANIST: Jurnal Manajemen dan Keuangan, Vol 9 (2), Desember 2021}

\section{PENDAHULUAN}

Pesatnya perkembangan Perguruan Tinggi di Indonesia semakin membuat kondisi persaingan dalam merebut pangsa pasar semakin ketat. Hal ini dikarenakan perguruan tinggi sebagai suatu institusi yang bergerak dibidang jasa harus dapat memberikan pelayanan jasa dibidang pendidikan yang berkualitas dan harus selalu memenuhi kebutuhan dan keinginan para pengguna jasa, salah satunya adalah mahasiswa.

Sementara informasi yang diperoleh dari beberapa mahasiswa bahwa mereka berpendapat masih kurang puas terhadap kinerja dosen antara lain materi yang tidak up-date, penyampaian materi yang tidak sesuai dengan RPS, penilaian yang tidak objektif dan lain-lainnya. Sementara di bidang sarana prasarana masih kurang antara lain fasilitas internet yang relatif terbatas, fasilitas AC yang tidak terlalu dingin, in-focus yang terkadang tidak dapat berfungsi sebagaiman mestinya. Begitu juga halnya di bidang pelayanan, mahasiswa masih mengeluhkan lambat pelayanan di bidang keuangan, pelayanan administrasi di fakultas serta lambatnya respon pemamngku kepentingan terhadap keluhan mahasiswa.

Representatif kepuasan mahasiswa adalah suatu keadaan terpenuhinya keinginan, harapan, dan kebutuhan mahasiswa (dalam Srinadi, 2008). Kepuasan mahasiswa adalah sikap positif mahasiswa terhadap pelayanan lembaga pendidikan tinggi karena adanya kesesuaianantara harapan dari pelayanan dibandingkan dengan kenyataan yang diterimanya (Sopiatin, 2010:33).

Fasilitas merupakan hal yang penting untuk diperhatikan dalam usaha jasa, terutama yang berkaitan erat dengan apa yang dirasakan oleh konsumen, karena dalam usaha jasa, penilaian konsumen terhadap suatu perusahaan didasari atas apa yang mereka peroleh setelah menggunakan jasa. Persepsi yang diperoleh dari interaksi pelanggan dengan fasilitas berpengaruh terhadap kualitas jasa dimata pelanggan (Tjiptono, 2014).

Universitas Muhammadiyah Bengkulu adalah salah satu perguruan tinggi swasta yang berdiri pada tahun 1991 di Bengkulu. Universitas Muhammadiyah Bengkulu saat ini memiliki 8 Fakultas yaitu Fakultas Ekonomi dan Bisnis, Fakultas Sosial dan Politik Fakultas Teknik, Fakultas Agama Islam, Fakultas Pertanian, Fakultas Keguruan Ilmu Pendidikan, Fakultas Kesehatan, Fakultas Hukum dan terdiri dari 23 Program Studi. Dalam memberikan pelayanan jasa dengan mengemban misi Catur Dharma Perguruan Tinggi, Universitas Muhammadiyah Bengkulu berkomitmen untuk selalu memberikan pelayanan yang bermutu secara profesional, inovatif dan penuh kepedulian serta menyempurnakan efektivitas sistem manajemen mutu secara berkesinambungan. Adapun tujuan umum penelitian ini adalah untuk mengetahui pengaruh kualitas pelayanan, fasilitas, serta kinerja dosen terhadap kepuasan mahasiswa Universitas Muhammadiyah Bengkulu secara simultan dan parsial.

\section{LANDASAN TEORI}

\section{Kepuasan Mahasiswa}

Kata kepuasan (satisfaction) berasal dari bahasa Latin "satis" (artinya cukup baik, memadai) dan "facio" (melakukan atau membuat). Kepuasan bisa diartikan sebagai "upaya pemenuhan sesuatu" atau "membuat sesuatu memadai" (Sarjono, 2007). Kepuasan asal katanya adalah puas yang berarti merasa senang, lega, kenyang, dan sebagainya karena sudah merasai secukupcukupnya atau sudah terpenuhi hasrat 
hatinya (Suharno dan Retnoningsih, 2012). Mahasiswa dalam Kamus Besar Bahasa Indonesia didefinisikan sebagai orang yang belajar diperguruan tinggi. Menurut Sugito kepuasan mahasiswa adalah suatu keadaan terpenuhinya keinginan, harapan, dan kebutuhan mahasiswa (Srinadi, 2008). Kepuasan mahasiswa adalah sikap positif mahasiswa terhadap pelayanan lembagapendidikan tinggi karena adanya kesesuaian antara harapan dari pelayanan dibandingkan dengan kenyataan yang diterimanya (Sopiatin, 2010). Indikator yang digunakan dalam penelitian ini adalah sebagai berikut: Kehandalan, Daya Tanggap, Kepastian, Empaty dan Berwujud (Alma, 2005).

\section{Kinerja Dosen}

Dalam perkembangan yang kompetitif dan mengglobal, setiap lembaga, termasuk lembaga pendidikan seperti Universitas Muhammadiyah Bengkulu membutuhkan personil, terutama tenaga dosen yang berprestasi tinggi. Pada saat yang sama setiap personil memerlukan umpan balik atas kinerja mereka sebagai pedoman bagi tindakan-tindakan mereka pada masa yang akan datang oleh karena itu penilaian yang dilakukan seharusnya menggambarkan kinerja personil (Lie et al., 2019). Hasil penilaian kinerja dapat menunjukkan apakah SDM yang ada telah memenuhi tuntutan yang dikehendaki lembaga, baik dilihat dari kualitas maupun kuantitas(Efendi et al., 2021). Informasi dalam penilaian kinerja personil merupakan refleksi dari berkembang tidaknya lembaga.Penilaian kinerja mengacu pada suatu system formal dan terstruktur yang digunakan untuk mengukur, menilai dan mempengaruhi sifatsifat yang berkaitan dengan pekerjaan, perilaku dan hasil (Sherly et al., 2021). Dengan dimikian, penilaian prestasi adalah merupakan hasil kerja personil dalam lingkup tanggung jawabnya. Kinerja dosen pada suatu perguruan tinggi merupakan perilaku nyata yang ditampilkan setiap dosen sebagai prestasi kerja yang dihasilkan oleh dosen tersebut sesuai dengan peranannya. Untuk dapat menentukan kualitas kinerja dosen perlu adanya criteria yang jelas. Menurut Supardi (2013) dapat disimpulkan pengertian kinerja adalah kemampuan seseorang dalam melaksanakan tugas atau pekerjaannya sesuai dengan tujuan yang ditetapkan berdasarkan bidang keahliannya dengan efektif dan efisien. Indikator yang digunakan dalam penelitian ini adalah sebagai berikut: Kualitas Hasil Kerja, Kemampuan, Prakarsa, Komunikasi dan Ketepatan Waktu (Peraturan Pemerintah No.60 tahun 1999).

\section{Kualitas Pelayanan}

Tjiptono (2011:59) menyatakan bahwa "Kualitas Pelayanan jasa adalah tingkat keunggulan yang diharapkan dan pengendalian atas tingkat keunggulan tersebut untuk memenuhi keinginan pelanggan". Menurut Lewis dan Booms (Tjiptono, 2012) menyatakan bahwa "ukuran seberapa bagus tingkat layanan yang diberikan mampusesuai dengan ekspektasi pelanggan.". Goeth dan Davis yang dikutip Tjiptono (2012) menyatakan bahwa "kualitas merupakan suatu kondisi dinamis yang berhubungan dengan produk, jasa, manusia, proses, dan lingkungan yang memenuhi atau melebihi harapan. Indikator yang digunakan dalam penelitian ini adalah sebagai berikut: Wujud Fisik, Daya Tanggap, Kehandalan, Keyakinan dan Empati (Kotler, 2012).

\section{Fasilitas}

Fasilitas adalah segala sesuatu yang bersifat peralatan fisik dan disediakan oleh 
pihak penjual jasa untuk mendukung kenyamanan konsumen (Kotler, 2013). Menurut Tjiptono (2011) fasilitas adalah sumber daya fisi yang harus ada sebelum suatu jasa dapat ditawarkan kepada konsumen. Fasilitas dapat pula berupa segala sesuatu yang memudahkan konsumen dalam memperoleh kepuasan. Fandi dalam Harsono (2012) mendefenisikan fasilitas sebagai variabel yang mempengaruhui kepuasan konsumen. Fasilitas yang disediakan di uinversitas, baik fasilitas pelayanan maupun non pelayanan juga mempengaruhi kepuasan konsumen. Semakin lengkap faslitas yang dimiliki maka semakin puas konsumen. Sama halnya menurut Wahyuningrum (2010), fasilitas adalah segala sesuatu yang dapat memudahkan dalam pelaksanaan suatu usaha. Sesuatu yang dapat memudahkan dan melancarkan usaha tersebut biasanya berupa benda-benda atau uang. Pengertian fasilitas berdasarkan Kamus Besar Bahasa Indonesia (2002) adalah sesuatu yang dapat membantu memudahkan pekerjaan, tugas dan sebagainya. Indikator yang digunakan dalam penelitian ini adalah sebagai berikut: Pertimbangan atau Perencanaan Parsial, Perencanaan Ruang, Perlengkapan atau Perabotan, Tata Cahaya, Warna dan PesanPesan yang disampaikan secara grafis (Tjiptono, 2011).

\section{Pengaruh Kinerja Dosen Terhadap ( $\left.\mathbf{X}_{1}\right)$} Terhadap Kepuasan Mahasiswa (Y)

Menurut Supardi (2013) dapat disimpulkan kinerja adalah kemampuan seseorang dalam melaksanakan tugas atau pekerjaannya sesuai dengan tujuan yang ditetapkan berdasarkan bidang keahliannya dengan efektif dan efisien sehingga tingkat kepuasan tinggi.

\section{Pengaruh Kualitas Pelayanan (X2) Terhadap Kepuasan Mahasiswa (Y)}

Kualitas pelayanan, dapat disimpulkan bahwa kualitas pelayanan adalah segala sesuatu yang diharapkan oleh konsumen agar perusahaan dapat memenuhi keinginan dan kebutuhan konsumen. Tjiptono (2011) menyatakan bahwa "Kualitas Pelayanan jasa adalah tingkat keunggulan yang diharapkan dan pengendalian atas tingkat keunggulan tersebut untuk memenuhi keinginan pelanggan".

\section{Pengaruh Fasilitas $\left(\mathbf{X}_{3}\right)$ Terhadap Kepuasan Mahasiswa (Y)}

Menurut Tjiptono (2011:184) fasilitas adalah sumber daya fisik yang harus ada sebelum suatu jasa dapat ditawarkan kepada konsumen. Fasilitas dapat pula berupa segala sesuatu yang memudahkan konsumen dalam memperoleh kepuasan. Fandi dalam Harsono (2012) mendefinisikan fasilitas sebagai variabel yang mempengaruhui kepuasan konsumen. Fasilitas yang disediakan, baik fasilitas pelayanan maupun non pelayanan juga mempengaruhi kepuasan konsumen.

\section{Kerangka Teoritik}

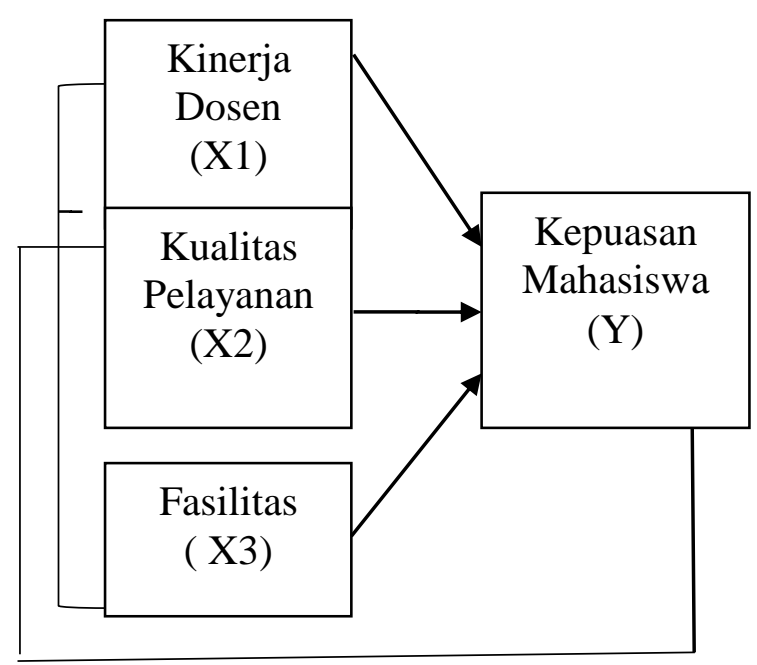

Gambar 1. Kerangka teoritik 


\section{SULTANIST: Jurnal Manajemen dan Keuangan, Vol 9 (2), Desember 2021}

\section{Hipotesis}

Adapun Hipotesis dalam penelitian ini adalah:

$\mathrm{H}_{1}$ : Diduga Kinerja Dosen berpengaruh terhadap Kepuasan Mahasiswa Universitas Muhammadiyah Bengkulu.

$\mathrm{H}_{2}$ : Diduga Kualitas Pelayanan berpengaruh terhadap Kepuasan

Mahasiswa Universitas Muhammadiyah Bengkulu.

$\mathrm{H}_{3}$ : Diduga Fasilitas berpengaruh terhadap

Kepuasan Mahasiswa Universitas Muhammadiyah Bengkulu.

$\mathrm{H}_{4}$ : Diduga Kinerja Dosen, Kualitas Pelayanan dan Fasilitas secara bersamasama mempengaruhi kepuasan mahasiswa Universitas Muhammadiyah Bengkulu.

\section{METODE}

Tempat untuk penelitian adalah Universitas Muhammadiyah Bengkulu kampus I dan IV yang akan dilaksanakan bulan September dan Oktober 2020. Jenis Penelitian yang digunakan dalam penelitian ini adalah metode deskriptif kuantitatif. populasi dalam penelitian ini adalah mahasiswa Universitas Muhammadiyah Bengkulu. Sampel yang digunakan pada penelitian ini sebanyak 637 orang responden. Teknik pengumpulan data menggunakan Kuesoner. Teknik aanalisis data dengan menggunakan Uji Regresi Linier Berganda, dan Uji Hipotesis yaitu Uji T dan Uji F.

\section{Uji Validitas}

Uji Validitas perlu dilakukan untuk mengetahui sejauh mana kuesioner dapat mengukur variabel penelitian. Uji validitas dilakukan untuk mengetahui apakah alat ukur tersebut memiliki ketepatan dalam melakukan pengukuran, atau dengan kata lain apakah alat ukur tersebut dapat benarbenar mengukur apa yang hendak diukur
(Arikunto, 2011). Proses validasi diawali dengan identifikasi mengenai atribut yang akan diukur yang dinyatakan dengan suatu konstruk dalam rumusan definisi konseptual berdasar suatu konsep teoritik tertentu. Kemudian dilakukan analisis statistik setelah criteria diuji cobakan pada sampel yang mewakili populasi sasaran subjek pengukuran. (Noor, 2013).

\section{Uji Reabilitas}

Reliabilitas adalah indeks yang menunjukkan sejauh mana suatu alat ukur dapat dipercaya atau dapat diandalkan, yang menunjukkan sejauh mana hasil pengukuran tetap konsisten (Suharsimi Arikunto 2011). Reliabilitas untuk mengetahui sejauh mana alat ukur yang digunakan tersebut memilliki taraf ketelitian, kepercayaan, kekonstanan ataupun kestabilan.

Bila suatu alat ukur dapat digunakan dua kali untuk mengukur gejala yang sama dengah hasil yang pengukuran yang relatif konsisten, maka alat ukur tersebut reliabel. Dalam aplikasinya, reliabilitas dinyatakan oleh koefisien reliabilitas yang angkanya berada dalam rentang dari 0 sampai dengan 1,00. Semakin tinggi koefisien reliabilitas mendekati angka 1,00 berati semakin tinggi reliabilitasnya. Juga sebaliknyam jika semakin rendah koefisien reliabilitas mendekati angka 0 berati semakin rendah reliabilitasnya.

\section{Analisis Regresi Linier Berganda}

Uji regresi bertujuan mengetahui ada tidaknya pengaruh secara parsialmaupun simultan antara variabel bebas $(\mathrm{X})$ terhadap variabel terikat (Y). Model analisis yang digunakan adalah model analisis regresi linear berganda. Model ini digunakan untuk mengetahui pengaruh variable independen terhadap variabel dependen dengan persamaan sebagai berikut: 


$$
\begin{aligned}
& Y=a+b_{1} X_{1}+b_{2} X_{2}+b_{3} X_{3}+\ldots . .+b_{n} X_{n} \\
& \text { Keterangan : } \\
& \mathrm{Y}=\text { Kepuasan Mahasiswa } \\
& \mathrm{X}_{1} \quad=\text { Kinerja Dosen } \\
& \mathrm{X}_{2} \quad=\text { Kualitas Pelayanan } \\
& \mathrm{X}_{3} \quad=\text { Fasilitas } \\
& \text { a } \quad=\text { Koefisien konstanta } \\
& \mathrm{b}_{1}, \mathrm{~b}_{2,}, \mathrm{~b}_{3}=\text { Koefisien Regresi } \\
& \mathrm{e}=\text { standar eror }
\end{aligned}
$$

\section{Uji T}

Uji $\mathrm{t}$ pada dasarnya menunjukan seberapa jauh pengaruh satu variabel bebas secara individual dalam menerangkan variabel terikat.

H0 : Kinerja Dosen, Kualitas Pelayanan, dan Fasilitas tidak mempunyai pengaruh signifikan secara parsial terhadap Kepuasan Mahasiswa Fakultas Ekonomi Universitas Muhammadiyah Bengkulu.

Ha : Kinerja Dosen, Kualitas Pelayanan, dan Fasilitas mempunyai pengaruh signifikan secara parsial terhadap Kepuasan Mahasiswa Fakultas Ekonomi Universitas Muhammadiyah Bengkulu.

\section{Uji F}

Uji $F$ dilakukan untuk mengetahui pengaruh variabel bebas secara bersamasama terhadap variabel terikat. Rumus uji $\mathrm{F}$ (Ghozali 2006).

H0 : Kinerja Dosen, Kualitas Pelayanan, dan Fasilitas tidak mempunyai pengaruh signifikan secara simultan terhadap Kepuasan Mahasiswa Fakultas Ekonomi Universitas Muhammadiyah Bengkulu.

Ha : Kinerja Dosen, Kualitas Pelayanan, dan Fasilitas mempunyai pengaruh signifikan secara simultan terhadap Kepuasan Mahasiswa Fakultas
Ekonomi Universitas Muhammadiyah Bengkulu.

\section{Koefisien Determinasi}

Pada model linear berganda ini, akan dilihat besarnya kontribusi untuk variabel bebas secara bersama-sama terhadap variabel terikatnya dengan melihat besarnya koefisien determinasi totalnya $\left(\mathrm{R}^{2}\right)$. Menurut Arikunto (2006), ada tidaknya korelasi dinyatakan angka pada indeks. Besar kecilnya indeks korelasi, jika bukan 0,000, berarti ada korelasi antara dua variabel yang di korelasikan.Semakin besar angka dalam indeks korelasi, maka semakin tinggi korelasi kedua variabel. Penafsiran terhadap kekuatan hubungan dari nilai koefisien korelasi berpedoman pada ketentuan menurut Sugiyono (2003) seperti tabel berikut: Jika (R) yang diperoleh mendekati 1 (satu) maka dapat dikatakan semakin kuat model tersebut menerangkan hubungan variabel bebas terhadap variabel terikat. Sebaliknya jika (R) makin mendekati 0 (nol) maka semakin lemah pengaruh variabelvariabel bebas terhadap variabel terikat. Besarnya kontribusi pengaruh ditentukan dalam persentasi yaitu ditentukan oleh koefisien Determinasi $\left(\mathrm{R}^{2)}\right.$ besarnya kontribusi bagi pengaruh variabel $\mathrm{X}$ terhadap variabel Y.

\section{HASIL DAN PEMBAHASAN}

\section{Hasil Penelitian \\ Uji Validitas}

Dari hasil pengolahan data diketahui nilai Corrected Item Total Correlation atau nilai untuk masing-masing variabel > (0.444). Hal ini menunjukkan bahwa item dari setiap pernyataan kuesioner masingmasing variabel tersebut adalah valid dan layak untuk digunakan dalam penelitian ini. Artinya item dari setiap pernyataan tersebut mampu mengukur dan menjelaskan variabelnya secara tepat. 
Uji Reabilitas

Tabel 1.

Uji Reabilitas

\begin{tabular}{|c|c|c|c|}
\hline No. & Variabel & $\begin{array}{c}\text { Cronbach's } \\
\text { Alpha }\end{array}$ & Keterangan \\
\hline 1. & $\begin{array}{c}\text { Kinerja Dosen } \\
\left(\mathrm{X}_{1}\right)\end{array}$ & 0.955 & Reliabel \\
\hline 2. & $\begin{array}{c}\text { Kualitas } \\
\text { Pelayanan }\left(\mathrm{X}_{2}\right)\end{array}$ & 0.949 & Reliabel \\
\hline 3. & Fasilitas $\left(\mathrm{X}_{3}\right)$ & 0.924 & Reliabel \\
\hline 4. & $\begin{array}{c}\text { Kepuasan } \\
\text { Mahasiswa (Y) }\end{array}$ & 0.881 & Reliabel \\
\hline
\end{tabular}

Sumber: Hasil Penelitian, 2021

Tabel diatas menunjukan hasil pengujian terhadap masing-masing variable, dapat disimpulkan bahwa semua variable menunjukan sebagai suatu ukuran yang reliabel, karena masing-masing Independ memiliki Independ's alpha $>0.60$.

\section{Uji T}

Untuk menguji pengaruh variabel bebas secara parsial terhadap variabel terikat digunakan uji t sebagai berikut:

Tabel 2. Uji T (Uji Secara Parsial)

\begin{tabular}{|c|c|c|c|c|c|c|}
\hline \multicolumn{7}{|c|}{ Coefficients $^{\mathrm{a}}$} \\
\hline & \multirow{2}{*}{ Model } & \multicolumn{2}{|c|}{$\begin{array}{c}\text { Unstandardized } \\
\text { Coefficients }\end{array}$} & \multirow{2}{*}{$\begin{array}{c}\begin{array}{c}\text { Standardized } \\
\text { Coefficients }\end{array} \\
\text { Beta }\end{array}$} & \multirow{2}{*}{$\mathrm{t}$} & \multirow{2}{*}{ Sig. } \\
\hline & & B & $\begin{array}{l}\text { Std. } \\
\text { Error }\end{array}$ & & & \\
\hline \multirow{4}{*}{1} & Constant & 2,406 & 0,944 & & 2,548 & 0,011 \\
\hline & $\begin{array}{c}\text { Kinerja } \\
\text { Dosen } \\
\text { (X1) }\end{array}$ & 0,037 & 0,010 & 0,120 & 3,825 & 0,000 \\
\hline & $\begin{array}{c}\text { Kualitas } \\
\text { Pelayanan } \\
\text { (X2) }\end{array}$ & 0,157 & 0,018 & 0,303 & 8,500 & 0,000 \\
\hline & $\begin{array}{l}\text { Fasilitas } \\
\text { (X3) }\end{array}$ & 0,334 & 0,029 & 0,406 & 11,636 & 0,000 \\
\hline
\end{tabular}

Sumber: Output SPSS 24 yang diolah, 2021

Dari hasil perhitungan diatas maka dapat dijelaskan bahwa Kinerja Dosen $\left(\mathrm{X}_{1}\right)$ menunjukkan nilai signfikansi sebesar 0,000 $<0.05$, karena nilai signifikansi lebih kecil dari 0.05, maka H0 ditolak dan Ha diterima. Artinya Kinerja Dosen $\left(\mathrm{X}_{1}\right)$ memiliki pengaruh yang positif dan signifikan terhadap Kepuasan Mahasiswa (Y). Hasil pengujian untuk variabel Kualitas Pelayanan
$\left(\mathrm{X}_{2}\right)$ menunjukkan nilai signfikansi sebesar $0,000<0.05$, karena nilai signifikansi lebih kecil dari 0.05, maka $\mathrm{H} 0$ ditolak dan $\mathrm{Ha}$ diterima. Artinya Kualitas Pelayanan $\left(\mathrm{X}_{2}\right)$ memiliki pengaruh yang positif dan signifikan terhadap Kepuasan Mahasiswa (Y).

Hasil pengujian untuk variabel Fasilitas $\left(\mathrm{X}_{3}\right)$ menunjukkan nilai signfikansi sebesar $0,000<0.05$, karena nilai signifikansi lebih kecil dari 0.05, maka $\mathrm{H} 0$ ditolak dan $\mathrm{Ha}$ diterima. Artinya Fasilitas $\left(\mathrm{X}_{3}\right)$ memiliki pengaruh yang positif dan signifikan terhadap Kepuasan Mahasiswa (Y).

\section{Uji F}

Dalam penelitian ini pengujian hipotesis dimaksudkan untuk mengukur besarnya pengaruh Kinerja Dosen $\left(\mathrm{X}_{1}\right)$, Kualitas Pelayanan $\left(\mathrm{X}_{2}\right)$ dan Fasilitas $\left(\mathrm{X}_{3}\right)$ terhadap Kepuasan Mahasiswa (Y), maka digunakan uji f. Berdasarkan hasil pengujian hipotesis Uji anova atau Uji f terlihat pada tabel sebagai berikut:

Tabel 3. Uji F (Uji Secara Simultan)

\begin{tabular}{|c|c|c|c|c|c|c|}
\hline \multicolumn{7}{|c|}{$\mathrm{ANOVA}^{\mathbf{a}}$} \\
\hline \multicolumn{2}{|c|}{ Model } & $\begin{array}{c}\text { Sum of } \\
\text { Square } \\
\mathrm{s}\end{array}$ & $\mathrm{df}$ & $\begin{array}{l}\text { Mean } \\
\text { Square }\end{array}$ & $\mathrm{F}$ & Sig. \\
\hline \multirow[t]{3}{*}{1} & $\begin{array}{l}\text { Regressi } \\
\text { on }\end{array}$ & $\begin{array}{r}3294,8 \\
86\end{array}$ & 3 & $\begin{array}{r}1098,2 \\
95\end{array}$ & $\begin{array}{r}172,5 \\
37\end{array}$ & $\begin{array}{r}.00 \\
0^{\mathrm{b}}\end{array}$ \\
\hline & Residual & $\begin{array}{r}4029,3 \\
93\end{array}$ & $\begin{array}{r}63 \\
3\end{array}$ & 6,366 & & \\
\hline & Total & $\begin{array}{r}7324,2 \\
79\end{array}$ & $\begin{array}{r}63 \\
6 \\
\end{array}$ & & & \\
\hline \multicolumn{7}{|c|}{ a. Dependent Variable: Kepuasan Mahasiswa (Y) } \\
\hline & $\begin{array}{l}\text { edictors: } \\
\text { Kualita }\end{array}$ & $\begin{array}{l}\text { onstant) } \\
\text { elayanar }\end{array}$ & 2) & s (X3), & erja I & \\
\hline
\end{tabular}

Sumber: Output SPSS 24 yang diolah, 2021

Hasil perhitungan statistik menunjukkan nilai signifikansi sebesar $0,000<0.05$. Karena nilai signifikansi dibawah 0.05 menunjukkan bahwa secara bersama-sama Kinerja Dosen $\left(\mathrm{X}_{1}\right)$, Kualitas Pelayanan $\left(\mathrm{X}_{2}\right)$ dan Fasilitas $\left(\mathrm{X}_{3}\right)$ mempunyai pengaruh yang positif dan signifikan terhadap Kepuasan Mahasiswa (Y). Maka berdasarkan hasil uji simultan, maka $\mathrm{H} 0$ ditolak dan $\mathrm{Ha}$ diterima, antara variabel-variabel bebas yaitu Kinerja Dosen 
$\left(\mathrm{X}_{1}\right)$, Kualitas Pelayanan $\left(\mathrm{X}_{2}\right)$ dan Fasilitas $\left(\mathrm{X}_{3}\right)$ mempunyai pengaruh yang signifikan secara bersama-sama terhadap Kepuasan Mahasiswa (Y).

\section{Koefisien Determinasi}

Tabel 4. Nilai Koefisien Determinasi Hasil Penelitian

\begin{tabular}{|l|c|c|c|c|}
\hline \multicolumn{5}{|c|}{ Model Summary $^{\mathbf{b}}$} \\
\hline & & & $\mathrm{R}$ \\
Model & $\mathrm{R}$ & $\begin{array}{c}\text { Adjusted } \\
\mathrm{R} \\
\text { Square }\end{array}$ & $\begin{array}{c}\text { Std. } \\
\text { Error of } \\
\text { the } \\
\text { Estimate }\end{array}$ \\
\hline 1 & $.671^{\mathrm{a}}$ & 0,450 & 0,447 & 2,523 \\
\hline \multicolumn{7}{|l|}{} \\
$\begin{array}{l}\text { a. Predictors: (Constant), Fasilitas (X3), Kinerja Dosen } \\
\text { (X1), Kualitas Pelayanan (X2) }\end{array}$ \\
\hline \multicolumn{2}{|l|}{ b. Dependent Variable: Kepuasan Mahasiswa (Y) } \\
\hline
\end{tabular}

Sumber: Output SPSS 24 yang diolah, 2021

Berdasarkan tabel diatas dapat diketahui bahwa nilai Adjusted $R$ square yang diguunakan untuk mengukur seberapa jauh kemampuan model dalam menerangkan variasi variabel dependen 0,447. Hal ini menunjukkan bahwa sebesar $44,7 \%$ Kepuasaan Mahasiswa Universitas Muhammadiyah Bengkulu dipengaruhi oleh variasi ketiga variabel independen, yaitu Kinerja Dosen $\left(\mathrm{X}_{1}\right)$, Kualitas Pelayanan $\left(\mathrm{X}_{2}\right)$ dan Fasilitas $\left(\mathrm{X}_{3}\right)$ terhadap Kepuasan Mahasiswa (Y), sedangkan sisanya (100\% $-44,7 \%=55,3 \%)$ dujelaskan oleh variabel - variabel diluar variabel penelitian ini.

Hasil penelitian disajikan dalam bentuk grafik, tabel, atau deskriptif. Analisis dan interpretasi hasil ini diperlukan sebelum dibahas. Hasil penelitian ditulis dalam bentuk paragraf mengalir yang ditulis dengan sistematis, analisis yang kritis, dan informatif.

Tabel dituliskan di tengah atau di akhir setiap teks deskripsi hasil/perolehan penelitian. Bila lebar Tabel tidak cukup ditulis dalam setengah halaman, maka dapat ditulis satu halaman penuh. Judul Tabel ditulis dari kiri rata tengah, semua kata diawali huruf besar, kecuali kata sambung. Kalau lebih dari satu baris dituliskan dalam spasi tunggal (at least 12). Sebagai contoh, dapat dilihat Tabel 1. Berikut

\section{Pembahasan}

H1 : Terdapat Pengaruh Kinerja Dosen Terhadap Kepuasan Mahasiswa Universitas Muhammadiyah Bengkulu. Berdasarkan hasil penelitian menunjukkan bahwa variabel Kinerja Dosen memiliki pengaruh secara positif terhadap Kepuasan Mahasiswa pada Mahasiswa Universitas Muhammadiyah Bengkulu Kampus I dan IV Di Kota Bengkulu. Jika Kinerja Dosen semakin ditingkatkan maka Kepuasan Mahasiswa akan semakin tinggi. Hal ini berarti bahwa Universitas Muhammadiyah Bengkulu mampu memberikan kinerja yang baik kepada mahasiswa yaitu melalui Kinerja Dosen yang selalu dikembangkan oleh Universitas. Kinerja Dosen dapat memberikan dorongan kepada Mahasiswa untuk menjalin hubungan yang kuat dengan Universitas Muhammadiyah Bengkulu. Dalam jangka panjang ikatan seperti ini memungkinkan Universitas Muhammadiyah Bengkulu untuk memahami dengan seksama harapan Mahasiswa serta kebutuhan mereka. Ketika mahasiswa menerima berbagai versi atau cara kinerja dosen yang dikembangkan oleh Universitas Muhammadiyah Bengkulu mereka percaya dan menerima nilai yang baik, dimana hal ini akan meningkatkan Kepuasan Mahasiswa itu sendiri. Hasil penelitian ini sejalan dengan teori Supardi (2013) dapat disimpulkan kinerja adalah kemampuan seseorang dalam melaksanakan tugas atau pekerjaannya sesuai dengan tujuan yang ditetapkan berdasarkan bidang keahliannya dengan efektif dan efisien sehingga tingkat kepuasan tinggi. Hal ini disebabkan kebutuhan, keinginan dan permintaan mahasiswa tidak selalu sama. Mahasiswa pasti akan selalu membandingkan terlebih dahulu tentang keunggulan dan kualitas yang ada di masing-masing Universitas sebelum mereka merekomendasikan. 
Hasil penelitian ini didukung oleh hasil penelitian yang dilakukan oleh Indah Ismiyati, (2010), yang menyatakan bahwa Kinerja Karyawan berpengaruh Positif dan Signifikan terhadap Kepuasan Pelanggan Hotel Sri Wibowo Yogyakarta.

\section{$\mathbf{H}_{2}$ : Terdapat Pengaruh Kualitas Pelayanan Terhadap Kepuasan Mahasiswa Universitas Muhammadiyah Bengkulu.}

Berdasarkan hasil penelitian menunjukkan bahwa variabel Kualitas Pelayanan memiliki pengaruh positif dan signifikan terhadap Kepuasan Mahasiswa pada Mahasiswa Universitas Muhammadiyah Bengkulu Kampus I dan IV Di Kota Bengkulu. Jika Kualitas Pelayanan semakin ditingkatkan maka Kepuasan Mahasiswa akan semakin tinggi terhadap pelayanan yang diberikan oleh Universitas Muhammadiyah Bengkulu. Hal ini berarti bahwa Universitas Muhammadiyah Bengkulu telah mampu memberikan kualitas pelayanan yang baik kepada mahasiswanya.

Adapun teori yang sejalan dengan penelitian ini yaitu menurut Tjiptono (2011) menyatakan bahwa "Kualitas Pelayanan jasa adalah tingkat keunggulan yang diharapkan dan pengendalian atas tingkat keunggulan tersebut untuk memenuhi keinginan pelanggan".

\section{H3 : Terdapat Pengaruh Fasilitas Terhadap Kepuasan Mahasiswa Universitas Muhammadiyah Bengkulu.}

Berdasarkan hasil penelitian menunjukkan bahwa variabel Fasilitass memiliki pengaruh positif dan signifikan terhadap Kepuasan Mahasiswa pada Mahasiswa Universitas Muhammadiyah Bengkulu Kampus I dan IV Di Kota Bengkulu. Jika Fasilitas semakin ditingkatkan maka Kepuasan Mahasiswa akan semakin tinggi terhadap pelayanan yang diberikan oleh Universitas Muhammadiyah Bengkulu. Hal ini bisa terjadi karena Mahasiswa merasa sangat nyaman dalam belajar karena fasilitas fasilitas yang diberikan oleh Universitas Muhammadiyah sangat mendukung, tanpa adanya fasilitas dan pencahayaan yang cukup proses pembelajaran pun tidak akan berjalan dengan lancar. Adapun teori yang sejalan dengan penelitian ini yaitu menurut Tjiptono (2011) fasilitas adalah sumber daya fisik yang harus ada sebelum suatu jasa dapat ditawarkan kepada konsumen. Fasilitas dapat pula berupa segala sesuatu yang memudahkan konsumen dalam memperoleh kepuasan.

Hasil penelitian ini diperkuat oleh penelitian yang dilakukan Thomas Aquinas Wahyu Adi Putranto, (2016), yang membuktikan bahwa fasilitas berpengaruh positif dan signifikan terhadap kepuasan konsumen (Studi Kasus Pada PT. Kereta Api Indonesia Daerah Operasional VI Yogyakarta).

H4 : Terdapat Pengaruh Kinerja Karyawan, Kualitas Pelayanan dan Fasilitas Terhadap Kepuasan Mahasiswa Universitas Muhammadiyah Bengkulu. Dapat disimpulkan bahwa Kinerja Dosen $\left(\mathrm{X}_{1}\right)$ memiliki pengaruh yang positif terhadap Kepuasan Mahasiswa (Y) hal ini dapat dilihat dari dorongan Universitass Muhammadiyah Bengkulu dalam mengembangkan Kinerja Dosen yang diberikan kepada Mahasiswa untuk menjalin hubungan yang kuat dalam jangka panjang, hal seperti ini memungkinkan Universitas Muhammadiyah Bengkulu untuk memahami dengan seksama harapan Mahasiswa serta kebutuhan mereka. Kualitas Pelayanan $\left(\mathrm{X}_{2}\right)$ memiliki pengaruh positif terhadap Kepuasan Mahasiswa (Y), hal ini dapat dilihat dari usaha Universitas 
Muhammadiyah Bengkulu dalam memberikan pelayanan yang baik kepada mahasiswanya. Fasilitas $\left(\mathrm{X}_{3}\right)$ memiliki pengaruh sangat besar terhadap Kepuasan Mahasiswa (Y). Dapat disimpulkan bahwa kepuasan dapat diperoleh apabila kinerja yang diberikan sangat menjamin, kualitas pelayanan yang baik dan fasilitas yang memadai sehingga mampu menarik minat maupun memberikan kepuasan tersendiri bagi yang merasakannya. Hasil penelitian ini diperkuat oleh penelitian yang dilakukan Reny wilija sihite, (2020), menyatakan bahwa kualitas pelayanan berpengaruh positif dan signifikan secara parsial terhadap kepuasan konsumen di Alfamart Marchelia Batam.

\section{SIMPULAN DAN SARAN}

\section{Simpulan}

Berdasarkan hasil penelitian yang telah dilakukan tentang Pengaruh Kinerja Dosen, Kualitas Pelayanan dan Fasilitas terhadap Kepuasan Mahasiswa pada Mahasiswa Universitas Muhammadiyah Bengkulu Kampus I dan IV Di Kota Bengkulu, dapat disimpulkan sebagai berikut:

1. Kinerja Dosen berpengaruh positif terhadap Kepuasan Mahasiswa pada Mahasiswa Universitas Muhammadiyah Bengkulu Kampus I dan IV Di Kota Bengkulu. Dengan adanya pemberian kinerja yang baik yang dilakukan oleh Universitas Muhammadiyah Bengkulu terhadap kinerja dosen yang diberikan akan meningkatkan Kepuasan Mahasiswa.

2. Kualitas Pelayanan berpengaruh positif terhadap Kepuasan Mahasiswa pada Mahasiswa Universitas Muhammadiyah Bengkulu Kampus I dan IV Di Kota Bengkulu. Kualitas Pelayanan memiliki pengaruh yang cukup besar terhadap Kepuasan Mahasiswa, jika pelayanan yang diberikan cocok dengan apa yang diharapkan oleh mahasiswa tersebut, maka akan menunbuhkan rasa kepuasan tersendiri kepada mahasiswa yang berpengaruh terhadap Kepuasan Mahasiswa dan sebaliknya.

3. Fasilitas berpengaruh positif terhadap Kepuasan Mahasiswa pada Mahasiswa Universitas Muhammadiyah Bengkulu Kampus I dan IV Di Kota Bengkulu. Fasilitas sangat berpengaruh besar terhadap Kepuasan Mahasiswa, sebab apabila fasilitas yang diberikan kepada mahasiswa sudah memenuhi keingan mereka, maka mahasiswa pun merasakan kepuasan saat melakukan kegiatan perkuliahan, hal tersebut sangat berpengaruh terhadap Kepuasan Mahasiswa dan begitupun sebaliknya.

4. Kinerja Dosen, Kualitas Pelayanan dan Fasilitas secara bersama-sama berpengaruh positif terhadap Kepuasan Mahasiswa pada Mahasiswa Universitas Muhammadiyah Bengkulu Kampus I dan IV Di Kota Bengkulu. Semakin baik Kinerja Dosen yang diberikan dengan memberikan pelayanan yang memuaskan dan fasilitas yang berkualitas baik yang dapat menciptakan kenyamanan bagi mahasiswa dalam menjalankan kegiatan dikampus.

5. Kepada Universitas Muhammadiyah Bengkulu dan dapat menciptakan Kepuasan Mahasiswa yang berkelanjutan.

\section{Saran}

Berdasarkan hasil penelitan, pembahasan dan kesimpulan yang diperoleh, maka saran yang dapat diberikan sebagai berikut:

a. Akademik

1. Kualitas pelayanan kepada mahasiswa agar ditingkatkan, dengan menempatkan 
mahasiswa adalah aset yang selalu dirawat, dijaga, diperhatikan dan dilayani secara prima.

2. Hasil penelitian terlihat bahwa pada variabel Kualitas Pelayanan $\left(\mathrm{X}_{2}\right)$ yang diberikan oleh Universitas Muhammadiyah Bengkulu Kampus I dan IV Di Kota Bengkulu berada pada kategori sedang. Disarankan lebih memperhatikan pelayanan kepada mahasiswa seperti pelayanan karyawan yang lebih cepat kepada mahasiswa agar tercipta kepuasan.

b. Praktis

1. Disarankan bagi peneliti selanjutnya khususnya penelitian yang sama perlu dipertimbangkan untuk faktor-faktor lain diluar variabel Kinerja Dosen, Kualitas Pelayanan dan Fasilitas terhadap Kepuasan Mahasiswa sehingga akan menghasilkan penelitian yang lebih baik.

\section{DAFTAR PUSTAKA}

Arikunto, Suharsimi. (2010). Manajemen Penelitian.Jakarta: PT Rineka CiptaHardiyansyah.

BuchariAlma, 2007.Manajemen Pemasaran dan Pemasaran Jasa. Cetakan Ketujuh. Bandung: CV Alfabeta.

Efendi, E., Harini, S., Simatupang, S., Silalahi, M., \& Sudirman, A. (2021). Can Job Satisfaction Mediate the Relationship between Emotional Intelligence and Spiritual Intelligence on Teacher Performance? Journal of Education Research and Evaluation, 5(1), 136.

Fandy, Tjiptono. 2011. Service management mewujudkan layanan prima.Edisi 2.Yogyakarta : andi.

Ghozali, Imam. 2011. "Aplikasi Analisis Multivariate Dengan Program SPSS". Semarang: Badan Penerbit Universitas Diponegoro.
Ibnu.(2011) Kualitas Pelayanan

Publik.Yogyakarta : Gava Media (12 Februari 2008). Kepuasan Pelanggan. (http://ibnudblog.blogspot.com,diakse s 29 Maret 2013.

Indah Ismiyati, (2010). Pengaruh Kinerja

Karyawan terhadap Kepuasan, kepercayaan dan Loyalitas konsumen. skripsi

JRMB, Volume 12, No. 2, Desember 2017 Pengaruh Karakteristik Individu, Budaya Kerja Dan Perilaku Individu Terhadap Kinerja Pegawai

Kotler, Philip dan kevin L. keller. 2009. Management pemasaran terj: bob sabran. Edisi 13 jilid 1 dan 2. Erlangga: Jakarta.

Kuncoro, Mudrajad, 2011 Metode Kuantitatif, UPP STIM YKPM, Yogyakarta.

Lie, D., Sherly, S., Dharma, E., \& Sudirman, A. (2019). The Impact of Work Discipline and Work Ethic on the Teacher Performance of Sultan Agung Pematangsiantar Private Middle School Teachers T.A. 2018/2019. International Journal of Business Studies, 3(3), 125-135.

Lovelock, C, dan John Wirtz, 2011. "Pemasaran Jasa Perspektif edisi 7”.Jakarta : Erlangga

Pedoman Umum Penyusunan Indeks Kepuasan Masyarakat Unit Pelayanan InstansiPemerintah. (2004).

Keputusan Menteri Pendayagunaan AparaturNegara Nomor: KEP/25/M.PAN/2/2004. Kementerian Pendayagunaan Aparatur Negara Republik Indonesia.

Ratminto. Atik Septi Winarsih. 2007. Manajemen Pelayanan. Yogyakarta: Pustaka Belajar.

Sarjono, Yetty, 2007, Faktor-Faktor Strategik Pelayanan Dosendan Dampaknya Terhadap Kepuasan 
Mahasiswa FKIP Universitas

Muhamadiyah Surakarta Tahun

Akademik 2005-2006, Varidika, Vol. 19, No. 1, 2007.

Sherly, S., Lie, D., Candra, V., Siallagan, D. M., \& Sudirman, A. (2021). Interpretation of the Effects of Job Satisfaction Mediation on the Effect of Principal Supervision and Compensation on Teacher Performance. Journal of Educational Science and Technology (EST), 7(1), 105-116.

https://doi.org/10.26858/est.v0i0.19208

Sopiatin, Popi. 2010. Manajemen Belajar

Berbasis Kepuasan Siswa.Bogor:

Ghalia Indonesia

Srinadi dan Nilakusmawati. 2008. "Faktor-

Faktor Penentu Kepuasan Mahasiswa

Terhadap Pelayanan Fakultas

Sebagai Lembaga Pendidikan (Studi

Kasus di FMIP, Universitas

Udayana)" Jurnal Cakrawala

Pendidikan. November. Th. XXVII

Sugiyono. 2013. Metode Penelitian

Kuantitatif Kualitatif dan $R \& D$.

Bandung: Alfabeta

Supranto, J. 2011. Pengukuran Tingkat Kepuasan Pelanggan Untuk Menaikkan Pangsa Pasar,Cetakan keempat, Penerbit PT Rineka Cipta, Jakarta

Tjiptono, Fandi. 2007. Stategi semasaran,Edisi ketiga, yogakarta

Wahyuningrum. 2008. Buku Ajar Manajemen Fasilitas Pendidikan. Yogyakarta: FIP UNY.

Yuda Supriyanto. (2012). Analisis Pengaruh Kualitas Pelayanan, Harga, dan Fasilitas Terhadap Kepuasan Pasien Rawat Jalan di Rumah Sakit Kariadi Semarang. Jurnal Manajemen. Universitas Diponegoro.

\section{PROFIL SINGKAT}

Dr.Islamuddin,S.E.,M.M Lulus S1 di Universitas Jambi tahun 1992, Lulus S2 di Universitas Muhammadiyah Jakarta, Lulus S3 Program Doktor Ilmu Manajemen Fakultas Ekonmoni dan Bisnis Universitas Bengkulu tahun 2021

Peneliti mengawali karier di bidang pendidikan, dengan mendirikan Lembaga Pendidikan Komputer Program 1 tahun di kota Bengkulu pada tahun 1996. Pada tahun 2000, Peneliti mendirikan Akademi Manajemen Informatika dan Komputer (AMIK) NUSANTARA Bengkulu, dan menjabat sebagai Direktur sampai tahun 2006. Dan pada tahun 2003, mendirikan sekolah tinggi, STMIK NUSANTARA Bengkulu, dan sekaligus sebagai Ketua. Pada tahun 2006, Peneliti menggabungkan AMIK-STMIK NUSANTAR Bengkulu ke Universitas Muhammadiyah Bengkulu, dan sejak tahun 2006 peneliti menjadi dosen pada Fakultas Ekonomi dan Bisnis Universitas Muhammadiyah Bengkulu. Pada tahun 2008 - 2011, sebagai Ketua Program Studi Manajemen UMB, tahun 2011 - 2014, sebagai Wakil Dekan I FEBI UMB. Tahun 2014 - 2018, sebagai Sekretaris Badan Penjaminan Mutu UMB, tahun 2018 - 2020, sebagai Wakil Dekan II dan III FEBI UMB dan tahun 2020 sampai dengan sekarang diberi amanah sebagai Wakil Dekan I dan IV FEBI UMB.

Drs.Khairul Bahrun.,M.M Lahir di Muara Aman tanggal 20 Agustus 1965. Telah menyelesaikan S1 di Universitas Bengkulu tahun 1990 serta menyelesaikan S2 di Program Magister Manajemen UNDIP Semarang tahun 2002. Saat ini adalah dosen tetap Program Studi Manajemen Universitas Muhammadiyah Bengkulu. Menjadi Dekan FE Tahun 2011 sampai 2013, Pengurus PW.PM Bengkulu tahun 2002 sampai 2006, Ketua LSBO PWM Tahun 2010 sampai 2015.

Ade Tiara Yulinda,S.E.,M.M Lulus S1 di Program Studi Manajemen FE Universitas Bengkulu tahun 2013, Lulus S2 
SULTANIST: Jurnal Manajemen dan Keuangan, Vol 9 (2), Desember 2021

Program Magister Manajemen tahun 2015 di Universitas Bengkulu. Saat ini adalah dosen tetap Program Studi Manajemen Universitas Muhammadiyah Bengkulu. Mengampuh mata kuliah Manajemen
Pemasaran. Menjadi pengurus komisariat UMB IAEI tahun 2018-2022.

Tongam Sihol Nababan, merupakan dosen tetap Fakultas Ekonomi Universitas HKBP Nommensen Medan. 